\title{
THE STUDENTS' ACHIEVEMENT IN PRONOUNCING ENGLISH SONG USING SMULE APPLICATION
}

\author{
Himatul Khoiriyah \\ English Education Department, Faculty of Education, \\ University of Technology Yogyakarta, Indonesia \\ E-mail: matul.hima@gmail.com
}

\author{
Ahmad Mustamir Waris \\ Tadris Bahasa Inggris, Fakultas Tarbiyah, IAIN Manado, Indonesia \\ E-mail: ahmadmustamirwaris@gmail.com \\ Juhansar \\ English Education Department, Faculty of Education, \\ University of Technology Yogyakarta, Indonesia \\ E-mail: juhansar@uty.ac.id
}

\begin{abstract}
APA Citation: Khoiriyah, H., Waris, A. M., \& Juhansar, J. (2018). The students' achievement in pronouncing English song using Smule application. Indonesian EFL Journal, 5(1), 45-58. doi: 10.25134/ieflj.v5i1.1610.
\end{abstract}

Received: 19-09-2018

Accepted: 21-11-2018

Published: 01-01-2019

\begin{abstract}
The development of science and technology forces academics to be more creative in the teaching- learning process to achieve a better quality of education. Smule application as a part of science and technology development should be used effectively and creatively as a tool in that process especially in English education field. Therefore, this research aims at describing the students' achievement in pronouncing English song using Smule application and finding out the factors influencing students' achievement in pronouncing English song using Smule application. This research used quantitative data with descriptive statistical approach. The data were collected through English pronunciation test and questionnaire. The English pronunciation test was used to collect the data related to students' English pronunciation achievement and the questionnaire was used to find out the factors influencing students' English pronunciation achievement. The results showed that the mean score of students' achievement in pronouncing English song using Smule application was 3.81 or almost good. It was influenced by the low frequency in practicing pronunciation, the difficulty to balance singing karaoke and music instruments on fast song tempo, and the lack of using Smule application to sing karaoke.
\end{abstract}

Keywords: achievement; English song; pronunciation; smule application; university students.

\section{INTRODUCTION}

Pronunciation is important in communication. Yet, there are some students choose to speak nothing because they do not know what to say and do not have confidence to produce the correct English pronunciation unlike writing where students are expressing and developing idea in a written form not in spoken form (Utami, Pabbajah, \& Juhansar, 2018, p. 115). If these happen for a long time, they will never build a good communication in English. A communication will run well when someone can use language properly by combining and synthesizing facts and ideas (Juhansar, et al., 2016, p. 88). As Backley (2015) said, the listener sometimes makes quick judgment about the speaker's pronunciation. If the pronunciation is poor, so it can break the overall language level. It indicates that we cannot omit those pronunciation features to deliver a clear and a good communication.

To understand English pronunciation well, students need to practice it more and more. To practice English pronunciation, students can use English song. Song is sound 
art which combines music composition and text or lyric. According to Encyclopedia of Americana (1998) in Farhati (2011), song refers to "the musical work which is set to phoetic text, with equal important given to the music and the words" (p.21). Basically, the composer writes song not only to deliver the message or feeling but also to entertain the listener. In singing a song, between lyrics and the instrument of music should be balanced by following the rhythm or tempo. Tempo refers to 'time' or 'musical time' (Drum, n.d.). It becomes the most important ingredient in creating music. There are three main tempos in music, namely slow, medium, and fast tempo. Each tempo has range of beats per minutes which popular with bpm (beat per minutes) that indicates the measurement of total beat that happens in a minute.

To learn English pronunciation through song, it must be based on the proper song's selection. The selection of song for learning English pronunciation is different in each educational level. The slow song (40-76 bpm) might be used for elementary, medium song (80-106 bpm) is for junior high school, moderate pace (108-116 $\mathrm{bpm}$ ) could be used in senior high school. For university level, it is better to use fast song (120-220 bpm) rather than slow or medium song. According to Voldánová (2017), to concern the vocabulary and pronunciation from song, students are better to be challenged to sing the fast song, because it can force students to listen the song carefully. Fast song is considered challenging especially for English Education Department students in exercising or learning pronunciation because they must keep up with the rhythm.

Song is usually found and listened when someone is watching TV, listening to radio, and streaming on the internet. Yet, since internet has been providing many things, song can also be found easily there. Nowadays, everyone has smartphone which connects to the internet, so songs can be searched through smartphone applications, such as Sportify Music, Joox Application, Apple Music, SoundCloud, etc. By the time goes by, a music streaming application is getting upgrade for better quality and feature. For instance, Joox application which is used by people as the music streaming application has been upgraded. It is not only to stream music, but also to sing karaoke where it provides many genres of song powered by Smule application. Smule is an application allowing the user to sing karaoke, play guitar and piano through smartphone (Woo, 2016, p. 1). All ages of music's lovers whether students or not, younger or older can use it as a medium to sing karaoke easily.

Karaoke is originally coming from Japanese which means singing without live orchestra (Ruismäki, Antti, \& Kimmo, 2013, p. 1222). Karaoke by using Smule application can be done solo, duet (pair), and group. The difference between Joox application and Smule application are on the features availability. According to Apkmb (2018), there are several advantage features of Smule application that one can use to sing a song. The first is self-recording option with video. Smule application is not only audio recording but also video recording application. User can use video filter to make his/her face looks brighter when he/she is recording his/her video. Second, sing like a star with audio effect. The users having bad voice do not need to worry when they would like to sing because Smule application provides professional features to edit voice easily. Users can edit their own voice by applying effects which is available as they need. Third, share on the global platform. Some persons have social media to inform their activity to their social media's friends. They may share or promote themselves, as they have ability to sing. They could record their voice and video when they are singing and then share it globally through social media, like Facebook, Twitter, Instagram, and WhatsApp Messenger. Fourth, duet with featured artists. It becomes prior feature of Smule application to sing karaoke with many artists without meeting directly. It is a prior feature where other application does not. 
Fifth, collaboration with the original singer. Smule application presents different experience by providing collaboration singing with the original singer. It makes the singer fans can sing together with their favorite singer.

Yet, Smule application also has disadvantages based on the information found in Smule application. Some of the disadvantages are; 1) users should pay about IDR $24.000 /$ month to be a VIP member, 2) not all songs can be sung soloist, 3) users must cost the VIP for it, not all artists or singers are using Smule, so it limits the user to sing collaboration with original singers of the song, and 4) has many ads - the annoying ads usually appear when the user open the application and or when user has done singing karaoke.

To sing karaoke using Smule application, the user should sing his/her lyrics part. If user sings as solo, the lyrics will not have different color. Meanwhile, for the collaboration singing, the user will be directed to sing the blue lyrics part, the partner of duet will be directed to sing the grey lyrics part, and orange for singing the lyrics together. If the user sings the song properly, such as good in the intonation, stars show how excellent the intonation appear when singing. People are free to choose what song they want to sing whether it is local or international songs. There are many international songs. One of them is English song. While they are singing and enjoying the English songs, they also can acquire and/or learn foreign language. Indeed, user can duet karaoke with artists, such as joining karaoke 'Say You Won't Let Go with James Arthur', 'Flash Light with Jessi J', 'We Don't Talk Anymore with Charlie Puth', 'Treat You Better with Shawn Mendes' and many more.

In relation to this research, there were some previous researches having similar topic which have been conducted before. First, research conducted by Rengifo's (2009) showed that karaoke was a lot of fun in which the students' pronunciation advanced greatly. Second, Farhati (2011)

\section{https://journal.uniku.ac.id/index.php/IEFLJ/index}

focused on explaining the effectiveness of using English songs as a medium to enhance students' ability in pronouncing the English voiced plosive consonant (b, d, g) sounds. Third, a research conducted by Manik (2015) showed that the mean score of posttest is higher than pre-test score meaning that English song is an effective medium to improve students' mastery in pronunciation.

Basically, the English words will be easy to pronounce if students listen to correct English pronunciation and practice it frequently and repeatedly. Pronouncing English words well is little bit difficult because students tend not to comprehend the pronunciation deeply. One way to make students listen and practice the pronunciation easily is by singing. Therefore, this research aims at finding out the information about students' achievement in pronouncing English song using Smule application and the factors influencing their achievement. Indeed, pronunciation here is limited to segmental features (vowels and consonants) and suprasegmental features (intonation, word stress, and rhythm). To achieve those purposes, this research attempts to address the following research questions: 1) What is students' achievement in pronouncing English song using smule application? and 2) What factors are influencing students' achievement in pronouncing English song using Smule application?

\section{METHOD}

To achieve the aims of this research, the researchers used quantitative research data with descriptive statistical approach as the research design. It deals with the data about the students' achievement in pronouncing English song using Smule application, and the factors influencing students' pronunciation achievement. According to Ary, Lucy, Chris, \& Asghar (2010), "Descriptive statistic procedure is basically a method of handling quantitative information; this procedure enables researchers to organize, summarize, and describe observation data" (p. 101). 
Furthermore, the participants of this research were fourth semester students of English Education Department, Faculty of Education, University of Technology Yogyakarta (UTY) in the academic year 2017/2018. The participants consist of twelve (12) students; four (4) males and eight (8) females. They were from one class. Indeed, the researchers selected all (12) students as participants in this research.

In collecting data, the researchers used two instruments, namely English pronunciation test and questionnaire. English pronunciation test was used to find out data on students' achievement in pronouncing English song that was practiced through duet singing using Smule application, while questionnaire was used to find out data on factors influencing students' English pronunciation achievement using Smule application. In collecting the data, the pronunciation test was conducted to the students by practicing singing the chosen English song using Smule application. The researchers contributed the lyric of the English song with phonetic transcription to the participants. Participants were given time for a week to prepare well on singing, such as identifying and understanding the song and the lyric before singing and recording video in form of documentation. The pronunciation test data were given score based on five (5) pronunciation practice skill scoring classifications. Related to the scoring process, the researchers gave score on the segmental features; vowels and consonants and suprasegmental features; intonation, word stress, and rhythm (Ma, 2015, p. 34; Gilakjani, 2012, pp.120-122). The pronunciation test which was collected in the form of video recording then analyzed using the following formula which is adopted from Riduwan and Sunarto (2013, p. 38):

$$
\text { Mean } \quad \begin{aligned}
(\bar{X}) & =\frac{\sum x_{\bar{i}}}{n} \\
\text { Where } \quad \bar{X} & =\text { the symbol of mean } \\
X_{\bar{i}} & =\text { the summation of each data } \\
n & =\text { total students }
\end{aligned}
$$

After conducting English pronunciation test, the students were asked to respond to the questionnaire by determining the factors influencing their achievement in pronouncing English song using Smule application. The researchers used closeended questionnaire consisting of 20 items with four (4) options to choose. It was started by explaining what to do with the questionnaire before asking the students to respond it. Based on the way to administrate the questionnaire, the researchers used mail questionnaire distribution to make it more effective and efficient. To administrate the questionnaire, the researchers contacted the participants one by one via WhatsApp Messenger application because they were in their semester's holiday where the researchers could not meet them up to contribute and to collect the data. The questionnaire data finding were calculated by using the following formula which is adapted from Riduwan and Sunarto (2013, p.23):

$$
\begin{aligned}
& \frac{f}{n} \times 100 \% \\
& \text { Where } \quad f=\text { the frequency of the answer } \\
& n=\text { total number of respondent }
\end{aligned}
$$

\section{RESULTS AND DISCUSSION}

The discussions on data finding are divided into two subsections following the research questions and the aims of the research. The first subsection is about students' achievement in English pronouncing and the second is about factors influencing students' achievement in pronouncing English song using Smule application.

\section{The students' achievement in pronouncing English song using Smule application}

Before conducting the pronunciation test, the researchers did several steps to ensure the work of the test. Here, the participants were asked to record duet English singing song with the original native singer of English using Smule application in the form of video. They sang in duet singing "Treat You Better" with Shawn Mendes, the native singer of English. It is fast song tempo with $220 \mathrm{bpm}$. The following picture is the 
Indonesian EFL Journal (IEFLJ)

Volume 5, Issue 1, January 2019

capture of student' video recording when she was duet singing with the original native singer of English:

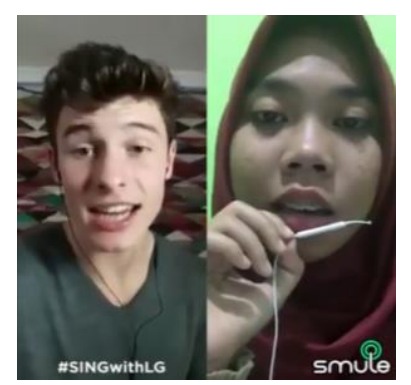

Figure 1. Duet singing "Treat You Better" song using Smule application
p-ISSN 2252-7427, e-ISSN 2541-3635

https://journal.uniku.ac.id/index.php/IEFLJ/index

In this stage, the researchers present the data that have been collected to be analyzed and discussed. Before that, the researchers determined the score of each feature. The researchers focus on segmental features, namely vowels (F1) and consonants (F2); and suprasegmental features, such as intonation (F3), word stress (F4), and rhythm (F5). The students' pronunciation would be said as excellent if the score is five (5), and poor if the score is one (1). To make it clear, the researchers present the frequency of students' achievement in each part using the English pronunciation test as follows.

Table 1. Score of students' English pronunciation test

\begin{tabular}{ccccccccc}
\hline \multirow{2}{*}{ No } & $\begin{array}{c}\text { Participants } \\
\text { Number }\end{array}$ & F1 & F2 & F3 & F4 & F5 & Total & \multirow{2}{*}{ Mean } \\
\hline 1 & 005 & 4 & 4 & 4 & 5 & 4 & 21 & 4.2 \\
2 & 006 & 3 & 4 & 5 & 4 & 5 & 21 & 4.2 \\
3 & 007 & 3 & 3 & 4 & 4 & 4 & 18 & 3.6 \\
4 & 008 & 4 & 4 & 5 & 5 & 5 & 23 & 4.6 \\
5 & 009 & 5 & 5 & 5 & 4 & 4 & 23 & 4.6 \\
6 & 010 & 3 & 4 & 4 & 4 & 4 & 19 & 3.8 \\
7 & 013 & 2 & 2 & 2 & 2 & 2 & 10 & 2 \\
8 & 015 & 4 & 4 & 5 & 5 & 5 & 23 & 4.6 \\
9 & 016 & 3 & 3 & 4 & 3 & 3 & 16 & 3.2 \\
10 & 017 & 3 & 3 & 4 & 4 & 4 & 18 & 3.6 \\
11 & 018 & 3 & 3 & 3 & 3 & 3 & 15 & 3 \\
12 & 022 & 4 & 4 & 5 & 5 & 5 & 23 & 4.6 \\
\hline \multicolumn{2}{c}{ Total } & $\mathbf{4 1}$ & $\mathbf{4 3}$ & $\mathbf{5 0}$ & $\mathbf{4 8}$ & $\mathbf{4 8}$ & & \\
\hline
\end{tabular}

Table 2. The work of Table 1; Students' English pronunciation test

\begin{tabular}{clccccccccccc}
\hline \multirow{2}{*}{ No } & Achievement & Score & \multirow{2}{*}{ F1 } & F2 & F3 & F4 & F5 & F1 & F2 & F3 & F4 & F5 \\
\cline { 2 - 7 } & Classification & $(\mathbf{x})$ & & & & $(\mathbf{x})$ & $(\mathbf{x})$ & $(\mathbf{x})$ & $(\mathbf{x})$ \\
\hline 1 & Excellent & 5 & 1 & 1 & 5 & 4 & 4 & 5 & 5 & 25 & 20 & 20 \\
2 & Good & 4 & 4 & 6 & 5 & 5 & 5 & 16 & 24 & 20 & 20 & 20 \\
3 & Average & 3 & 6 & 4 & 1 & 2 & 2 & 18 & 12 & 3 & 6 & 6 \\
4 & Poor & 2 & 1 & 1 & 1 & 1 & 1 & 2 & 2 & 2 & 2 & 2 \\
5 & Very Poor & 1 & - & - & - & - & - & - & - & - & - & - \\
\hline \multicolumn{2}{r}{ Total } & & 12 & 12 & 12 & 12 & 12 & $\mathbf{4 1}$ & $\mathbf{4 3}$ & $\mathbf{5 0}$ & $\mathbf{4 8}$ & $\mathbf{4 8}$ \\
\hline
\end{tabular}

Table 3. The mean score of students English pronunciation test

\begin{tabular}{clccc}
\hline No & \multicolumn{1}{c}{ Features } & $\boldsymbol{X}$ (score summation) & $\boldsymbol{n}$ (Number of Students) & $\overline{\boldsymbol{X}}$ (Mean) \\
\hline 1 & Vowels (F1) & 41 & 12 & 3.41 \\
2 & Consonants (F2) & 43 & 12 & 3.58 \\
3 & Intonation (F3) & 50 & 12 & 4.10 \\
4 & Word Stress (F4) & 48 & 12 & 4.00 \\
5 & Rhythm (F5) & 48 & 12 & 4.00 \\
\hline & & & Total & $\mathbf{1 9 . 0 9}$ \\
\hline
\end{tabular}

Those are the result of mean score on work table. It shows that the mean score of vowels (F1) is 3.41 and the consonant (F2) is
3.58. It indicates that the mean score of segmental feature is 3.49 or average. Meanwhile, the suprasegmental feature is 
good. It is proven by the mean score of intonation (F3) is 4.10, word stress (F4) is 4.00 , and the rhythm (F5) with mean score 4.00. The mean score for suprasegmental feature is 4.03. Indeed, the researchers conclude that the achievement of twelve (12) students of fourth semester of English Education Department, Faculty of Education, University of Technology Yogyakarta in academic year 2017/2018 in pronouncing English song using Smule application is 3.81 which includes on above average category. Based on the results, the researchers are interested to see the factors influencing their achievement.
The factors influencing students' achievement in pronouncing English song using Smule application

Based on the result of pronunciation test above, the researchers believe that there are some factors influencing the students' achievement in pronouncing the English song. Those factors are explained based on the results of questionnaire that has been responded by the students. This is a closeended questionnaire which consists of 20 items, and it was analyzed individually. The analysis result is described below.

Table 4. Students' opinion about their own pronunciation

\begin{tabular}{clcc}
\hline No & Classification & Frequency & Percentage \\
\hline 1 & Excellent & - & - \\
2 & Good & 2 & $16.67 \%$ \\
3 & Average & 8 & $66.66 \%$ \\
4 & Poor & 2 & $16.67 \%$ \\
\hline & Total & $\mathbf{1 2}$ & $\mathbf{1 0 0 \%}$ \\
\hline
\end{tabular}

Table 4 shows that none of students who consider his pronunciation is excellent. There are 2 or $16.67 \%$ of 12 students think that they have good pronunciation; most of students or $8(66.66 \%)$ students believe that their pronunciation is average; and 2 or $16.67 \%$ students claim having poor pronunciation. By those results, they seem happy with their ability as proven in the following table.

Table 5. Students' feelings when they are listening to their English words pronunciation

\begin{tabular}{clcc}
\hline No & Classification & Frequency & Percentage \\
\hline 1 & Very Happy & 2 & $16.67 \%$ \\
2 & Happy & 7 & $58.33 \%$ \\
3 & Unhappy & 2 & $16.67 \%$ \\
4 & Don't Care & 1 & $8.33 \%$ \\
\hline & Total & $\mathbf{1 2}$ & $\mathbf{1 0 0 \%}$ \\
\hline
\end{tabular}

Table 5 shows the students' feeling when they are listening to their own pronunciation. There are 2 or $16.67 \%$ students feel very happy with it; 7 or $58.33 \%$ of 12 students state they are happy; 2 or $16.67 \%$ students feel unhappy; and only 1 or $8.33 \%$ student state don't care about his/her pronunciation. The following table tells about the students' frequency in listening to English song 1.

Table 6. Students' frequency in listening English song 1

\begin{tabular}{clcc}
\hline No & Classification & Frequency & Percentage \\
\hline 1 & Always & 7 & $58.33 \%$ \\
2 & Sometimes & 4 & $33.33 \%$ \\
3 & Seldom & 1 & $8.33 \%$ \\
4 & Never & - & - \\
\hline & Total & $\mathbf{1 2}$ & $\mathbf{1 0 0 \%}$ \\
\hline
\end{tabular}


Table 6 shows that from 12 students, there are $7(58.33 \%)$ students who always listen to English song; 4 or $33.33 \%$ of 12 students only listen it sometimes; 1 (8.33\%) student shows that the intensity of listening
https://journal.uniku.ac.id/index.php/IEFLJ/index

to English song is seldom; but none of students who never listen it. It is supported by Table 7 which shows the time frequency of students in listening to English song 2 as follows.

Table 7. Students' time frequency in listening to English song 2

\begin{tabular}{clcc}
\hline No & Classification & Frequency & Percentage \\
\hline 1 & Every Day & 7 & $58.33 \%$ \\
2 & Twice A Week & 2 & $16.67 \%$ \\
3 & Once A Week & 1 & $8.33 \%$ \\
4 & Not at All & 2 & $16.67 \%$ \\
\hline & Total & $\mathbf{1 2}$ & $\mathbf{1 0 0 \%}$ \\
\hline
\end{tabular}

In line with Table 6 , Table 7 proves that 7 or $58.33 \%$ students listen to English song every day. There are $2(16.67 \%)$ students mention that they usually listen to English song twice a week. 1 or $8.33 \%$ student states that he/she listens to English song only once a week; and 2 or $16.67 \%$ students claim not at all which indicates that they listen to English song out of the available options or even they do not listen to. To know the time frequency of students in listening to English song in a day, the researchers present the following table.

Table 8. Students' time frequency in listening to the English song in a day

\begin{tabular}{clcc}
\hline No & Classification & Frequency & Percentage \\
\hline 1 & More than One Hour & 7 & $58.33 \%$ \\
2 & One Hour & 1 & $8.33 \%$ \\
3 & Half an Hour & 3 & $25.00 \%$ \\
4 & Not at All & 1 & $8.33 \%$ \\
\hline \multicolumn{2}{c}{ Total } & $\mathbf{1 2}$ & $\mathbf{1 0 0 \%}$ \\
\hline
\end{tabular}

Based on Table 8 , we can see that $58.33 \%$ or 7 from 12 students can spend more than one hour in a day to listen the English song. It seems that a song has been an additional part of their life accompanying their daily activities. Meanwhile, 1 student or $8.33 \%$ do it for one hour; 3 of 12 (25.00\%) students only spend half an hour to listen; and $1(8.33 \%)$ said not at all. The following table shows how students' opinion related to the native singer of English pronunciation in singing the English song.

Table 9. Students' opinion about the native singer of English pronunciation

\begin{tabular}{clcc}
\hline No & Classification & Frequency & Percentage \\
\hline 1 & Excellent & 5 & $41.67 \%$ \\
2 & Good & 6 & $50.00 \%$ \\
3 & Average & 1 & $8.33 \%$ \\
4 & Poor & - & - \\
\hline & Total & $\mathbf{1 2}$ & $\mathbf{1 0 0 \%}$ \\
\hline
\end{tabular}

As non-native speaker of English, Indonesian students tend to point out the native English singer as their paragon in pronouncing the English words or sentences. We can see in Table 9, among 12 students, there are $6(50.00 \%)$ students think that the native singer of English has good pronunciation. The 5 or $41.67 \%$ students consider that it is excellent; $8.33 \%$ or 1 student state that it is average. None of students thinks the native singer of English have poor pronunciation. Table 10 presents the students' reaction when they are listening to the native singer of English pronunciation. 
Table 10. Students' feeling when native singer of English pronounces English words

\begin{tabular}{clcc}
\hline No & Classification & Frequency & Percentage \\
\hline 1 & Very Happy & 5 & $41.67 \%$ \\
2 & Happy & 6 & $50.00 \%$ \\
3 & Unhappy & - & - \\
4 & Don't Care & 1 & $8.33 \%$ \\
\hline & Total & $\mathbf{1 2}$ & $\mathbf{1 0 0 \%}$ \\
\hline
\end{tabular}

From Table 10, we can see that 5 (41.67\%) students state very happy, 50.00\% or a half of 12 students feel happy, none of students who is unhappy to listen the native singer of English pronunciation, and 1
$(8.33 \%)$ student states that he/she doesn't care about it. Table 11 below presents the students' reaction in singing the English song.

Table 11. Students' interest to sing the English song

\begin{tabular}{clcc}
\hline No & Classification & Frequency & Percentage \\
\hline 1 & Very Interested & 3 & $25.00 \%$ \\
2 & Interested & 8 & $66.67 \%$ \\
3 & Less Interested & 1 & $8.33 \%$ \\
4 & Not Interested & - & - \\
\hline & Total & $\mathbf{1 2}$ & $\mathbf{1 0 0 \%}$ \\
\hline
\end{tabular}

As English Education Department students, their attraction to sing English song is high enough. It shows that there are 8 of 12 or $66.67 \%$ students who state that they feel interested to do it. There are 3 or $25.00 \%$ students are very interested; and only 1 or $8.33 \%$ student feels less interested. There is none of students who is not interested in it. Next, the researchers present the pronunciation frequency of English Education Department as in the following table.

Table 12. Students' frequency in practicing English pronunciation

\begin{tabular}{clcc}
\hline No & Classification & Frequency & Percentage \\
\hline 1 & Always & - & - \\
2 & Sometimes & 2 & $16.67 \%$ \\
3 & Seldom & 10 & $83.33 \%$ \\
4 & Never & - & - \\
\hline & Total & $\mathbf{1 2}$ & $\mathbf{1 0 0 \%}$ \\
\hline
\end{tabular}

Data in Table 12 contrasts with data in Table 11 where most of students are interested in singing English song. As it can be seen in Table 12, there are only 2 (16.67\%) students who state that they sometimes practice English words, and the others $10(83.33 \%)$ students state seldom practice the English words pronunciation.
Then, none of students who states always and never. It indicates that students only like to listen to English song as shown in Table 6,7 , and 8 , rather than to practice the English words pronunciation. The following table presents the students' opinion about practicing pronunciation through English song.

Table 13. Students' opinion about pronouncing English words through English song

\begin{tabular}{clcc}
\hline No & Classification & Frequency & Percentage \\
\hline 1 & Strongly Agree & 4 & $33.33 \%$ \\
2 & Agree & 7 & $58.33 \%$ \\
3 & Disagree & 1 & $8.33 \%$ \\
4 & Strongly Disagree & - & - \\
\hline \multicolumn{2}{r}{ Total } & $\mathbf{1 2}$ & $\mathbf{1 0 0 \%}$ \\
\hline
\end{tabular}


Table 13 shows that 4 of 12 or $33.33 \%$ students strongly agree that English song is a good medium to practice English pronunciation; 7 (58.33\%) students mention agree; 1 or $8.33 \%$ student claim disagrees;
https://journal.uniku.ac.id/index.php/IEFLJ/index

and none of students strongly disagree with that statement. The following table presents the students' opinion related to song genre which is easy to sing.

Table 14. Students' opinion about the tempo of song that is easy to sing

\begin{tabular}{clcc}
\hline No & Classification & Frequency & Percentage \\
\hline 1 & Slow & 5 & $41.67 \%$ \\
2 & Medium & 6 & $50.00 \%$ \\
3 & Fast & 1 & $8.33 \%$ \\
4 & Not at All & - & - \\
\hline & Total & $\mathbf{1 2}$ & $\mathbf{1 0 0 \%}$ \\
\hline
\end{tabular}

From Table 14, it can be seen that there are $50.00 \%$ or 6 students consider that medium song tempo is easy to sing. The students who like slow song tempo to sing is 5 or $41.67 \%$ students. Meanwhile, from 12 students, there is only 1 (8.33\%) student who states that fast song is the easiest song tempo to sing than slow and medium. It indicates that all song tempos can be reached to sing by the students because none of students who mentions not at all as their opinion about it. Next, Table 15 presents students' recognition about Smule application.

Table 15. Students' recognition about Smule application

\begin{tabular}{clcc}
\hline No & Classification & Frequency & Percentage \\
\hline 1 & Yes & 10 & $83.33 \%$ \\
2 & No & 2 & $16.67 \%$ \\
\hline & Total & $\mathbf{1 2}$ & $\mathbf{1 0 0 \%}$ \\
\hline
\end{tabular}

Based on Table 15, we can see that 10 out of 12 students state that they know Smule application. It indicates that Smule application has been familiar for them. There are two or $16.67 \%$ of students do not know about it. Students' frequency in using Smule application is shown in Table 16.

Table 16. Students frequency in using Smule application to sing karaoke

\begin{tabular}{clcc}
\hline No & Classification & Frequency & Percentage \\
\hline 1 & Always & - & - \\
2 & Sometimes & 2 & $16.67 \%$ \\
3 & Seldom & 9 & $75.00 \%$ \\
4 & Never & 1 & $8.33 \%$ \\
\hline & Total & $\mathbf{1 2}$ & $\mathbf{1 0 0 \%}$ \\
\hline
\end{tabular}

Table 15 is in contrast with Table 16. Table 15 shows that most of students know about Smule application but if we look at Table 16, there are only 2 students or $16.67 \%$ who state sometimes, 1 (8.33\%) student states never, and most of students are seldom using Smule application to sing karaoke. It is proven by the 9 or $75.00 \%$ of students who state seldom and no student said always. Based on the research, it can be concluded that even though students know Smule application, it does not mean that they will use it to sing karaoke or to practice pronouncing the English song. Table 17 presents the students' experience in using Smule application. 
Table 17. Students' opinions about Smule application as medium to practice pronunciation

\begin{tabular}{clcc}
\hline No & Classification & Frequency & Percentage \\
\hline 1 & Strongly Agree & 1 & $8.33 \%$ \\
2 & Agree & 10 & $83.33 \%$ \\
3 & Disagree & 1 & $8.33 \%$ \\
4 & Strongly Disagree & - & - \\
\hline \multicolumn{2}{r}{ Total } & $\mathbf{1 2}$ & $\mathbf{1 0 0 \%}$ \\
\hline
\end{tabular}

Based on students' experience in using Smule application, there are 10 of 12 students who agree with the statement that Smule application is a good application to practice English pronunciation. It is proven by the result on Table 17 that 10 students or
$83.33 \%$ agree about it. The others strongly agree and disagree with each percentage is $8.33 \%$ or 1 student and no students strongly disagree. The following table presents the students' motivation to use Smule application.

Table 18. Students' motivation to use Smule application in practicing pronunciation

\begin{tabular}{clcc}
\hline No & Classification & Frequency & Percentage \\
\hline 1 & Strongly Agree & - & - \\
2 & Agree & 7 & $58.33 \%$ \\
3 & Disagree & 5 & $41.67 \%$ \\
4 & Strongly Disagree & - & - \\
\hline \multicolumn{2}{r}{ Total } & $\mathbf{1 2}$ & $\mathbf{1 0 0 \%}$ \\
\hline
\end{tabular}

We can see from Table 18, there are about $58.33 \%$ or 7 students agree; and 5 (41.67\%) students disagree. None of students who strongly agrees and strongly disagrees about Smule application as a medium to increase their motivation in pronouncing English words or sentences through English song. To know students' reaction about pronouncing English song by using Smule application, the researchers present the result of questionnaires' item in the following table.

Table 19. Students' reaction in pronouncing English song using Smule application

\begin{tabular}{clcc}
\hline No & Classification & Frequency & Percentage \\
\hline 1 & Strongly Agree & 1 & $8.33 \%$ \\
2 & Agree & 10 & $83.33 \%$ \\
3 & Disagree & 1 & $8.33 \%$ \\
4 & Strongly Disagree & - & - \\
\hline \multicolumn{2}{r}{ Total } & $\mathbf{1 2}$ & $\mathbf{1 0 0 \%}$ \\
\hline
\end{tabular}

Table 19 shows that most of students agree that pronouncing English song using Smule application is not boring. It is shown by the 10 students or $83.33 \%$ who agree about it. The other students mention that they strongly agree and disagree with similar percentage $8.33 \%$ or 1 student; and none of students strongly disagree about it. Next, the students' view about Smule application is shown in the following table.

Table 20. Students' opinions on duet singing using Smule application helps to imitate good pronunciation

\begin{tabular}{clcc}
\hline No & Classification & Frequency & Percentage \\
\hline 1 & Strongly Agree & 3 & $25.00 \%$ \\
2 & Agree & 8 & $66.67 \%$ \\
3 & Disagree & 1 & $8.33 \%$ \\
4 & Strongly Disagree & - & - \\
\hline \multicolumn{2}{r}{ Total } & $\mathbf{1 2}$ & $\mathbf{1 0 0 \%}$ \\
\hline
\end{tabular}


According to students' opinion as in Table 20, duet singing with an English native singer helps students to imitate good pronunciation. It is proven by 8 of 12 or $66.67 \%$ students who agree with that statement. 3 or $25.00 \%$ students strongly

\section{https://journal.uniku.ac.id/index.php/IEFLJ/index}

agree; 1 (8.33\%) student disagrees; and none of students strongly disagree about it. Next, the researchers present the data about imitating native singer of English which is shown in the following table.

Table 21. Imitate the native singer of English pronunciation makes students be better in pronouncing English words

\begin{tabular}{clcc}
\hline No & Classification & Frequency & Percentage \\
\hline 1 & Strongly Agree & - & - \\
2 & Agree & 8 & $66.67 \%$ \\
3 & Disagree & 3 & $25.00 \%$ \\
4 & Strongly Disagree & 1 & $8.33 \%$ \\
\hline \multicolumn{2}{c}{ Total } & $\mathbf{1 2}$ & $\mathbf{1 0 0 \%}$ \\
\hline
\end{tabular}

As it can be seen in Table 21, most of students agree that imitating native singer of English help them to have a good and correct English pronunciation. It is supported by $66.67 \%$ or 8 students who agree to the statement. Students who disagree with the statement are 3 or $25.00 \%$; and who strongly disagrees about it is $8.33 \%$ or 1 student. None of students states strongly agree that imitating native singer of English help his/her English pronunciation be better. The following table presents the students' experience in using Smule application to sing karaoke.

Table 22. Students' experience in using Smule application to sing karaoke

\begin{tabular}{clcc}
\hline No & Classification & Frequency & Percentage \\
\hline 1 & Very Interested & 1 & $8.33 \%$ \\
2 & Interested & 7 & $58.33 \%$ \\
3 & Less Interested & 1 & $8.33 \%$ \\
4 & Not Interested & 3 & $25.00 \%$ \\
\hline & Total & $\mathbf{1 2}$ & $\mathbf{1 0 0 \%}$ \\
\hline
\end{tabular}

Regarding to students' experiences in using Smule application shown in Table 22, there are 7 of 12 or $41.67 \%$ students who interested in using Smule application. It happens because Smule supports the singing activity with its features. Meanwhile, 1 or $8.33 \%$ student states very interested and 1 $(8.33 \%)$ student mentions less interested.
Even though Table 20 shows that most of students do not feel bored when using Smule application, it does not work in this case. There are $3(25.00 \%)$ students who are not interested in using Smule application. The following table shows students' opinion about Smule application to pronounce English song.

Table 23. Students' opinions about Smule application to pronunciation (helpful or not)

\begin{tabular}{clcc}
\hline No & Classification & Frequency & Percentage \\
\hline 1 & Strongly Agree & - & - \\
2 & Agree & 7 & $58.33 \%$ \\
3 & Disagree & 5 & $41.67 \%$ \\
4 & Strongly Disagree & - & - \\
\hline \multicolumn{2}{r}{ Total } & $\mathbf{1 2}$ & $\mathbf{1 0 0 \%}$ \\
\hline
\end{tabular}

Table 23 shows that most of students agree that Smule application helps them in achieving better English pronunciation. It is proven by 7 or $41.67 \%$ students who agree;
$5(41.67 \%)$ students disagree; and none of students states strongly agree and strongly disagree about it. 
Based on the questionnaire data analysis, the researchers explore some factors which are influencing the students' achievement in pronouncing English song using Smule application. There are 3 factors influencing the achievement of fourth semester students of English Education Department, Faculty of Education, University of Technology Yogyakarta, academic year 2017/2018 in pronouncing English song. First, table 12 (item 9) shows that 10 of 12 or $83.33 \%$ students mention seldom to pronounce English song using Smule application. It indicates that the students' frequency in pronouncing English words or sentences is lack. They only like to listen rather than to pronounce it. Hence, to have good pronunciation, students need to not only listen to the English song, but also practice it. Second, based on the selection of song tempo, learning pronunciation through song for university students should use fast song tempo. Yet, Table 14 (item 11) shows that 6 or $50.00 \%$ students choose medium as the easiest songs tempo to sing. It means that students cannot follow or balance with the determined song tempo. Third, most of students on item 17 (Table 20) agree that imitating a native singer of English pronunciation helps their English pronunciation be better. Yet, Table 16 (item 13) proves that 9 or $75.00 \%$ students seldom use Smule application to sing karaoke. They should use Smule application more frequently because only in Smule application they can sing and imitate the pronunciation through singing duet with the native singer of English.

\section{CONCLUSION}

Based on the data analysis of students' mean score and questionnaire that have been presented and discussed, it is found that the mean of segmental features' score; vowels $(\mathrm{F} 1)$ is 3.41 and consonants (F2) is 3.48 . Both are included into the average category. Meanwhile, for the mean of suprasegmental features' score is good. It is proven by intonation (F3) is 4.10 , word stress (F4) is 4.00 , and the rhythm (F5) is 4.00 . Based on the segmental and suprasegmental features mean score, the overall mean score for students' pronunciation is 3.81. Thus, it can be concluded that the achievement of fourth semester students of English Education Department, Faculty of Education, University of Technology Yogyakarta, academic year 2017/2018 in pronouncing English song was almost good or equal to 3.81. Furthermore, the researchers found 3 (three) factors influencing the achievement of fourth semester students of English Education Department, Faculty of Education, University of Technology Yogyakarta, academic year 2017/2018 in pronouncing English song using Smule application. First, students have low frequency in practicing English pronunciation. Second, students feel it is difficult to balance singing karaoke and music instruments on fast song tempo. Third, students lack of using Smule application to sing karaoke.

\section{REFFERENCES}

Apkmb. Sing! Karaoke by Smule v5.3.3 VIP Unlocked [New Fixes] APK [Latest]. Retrieved March 2, 2018, from https://apkmb.com/singkaraoke-by-smule-apk/.

Ary, D., Lucy, C. J, Chris, S., \& Asghar, R. (2010). Introduction to research in education $\left(8^{\text {th }} \mathrm{ed}\right.$.). USA: Wadsworth, Cangage Learning.

Backley, P. (2015). Improve your English pronunciation. Retrieved March 1, 2018, from http://toefl.uobabylon.edu.iq/papers/pearson_20 15_12619610.pdf.

Drum, J. (n.d.). Tempo in music: Education assistant the Phoenix Symphony. Retrieved April 11, 2018, from: https://www.phoenixsymphony.org/uploads/Te mpo.pdf.

Farhati, A. T. (2011). The effectiveness of English songs as media to enhance students' ability to pronounce English plosive voiced consonants $(b, d, g)$. Unpublished master thesis. Department of English and Art, Semarang State University.

Gilakjani, A. P. (2012). A study of factors affecting EFL learner's English pronunciation learning and the strategies for instructions. International Journal of Humanities and Social Science, 2(3), 120-122.

Juhansar, Mustaqim, P., \& Sayit, A. K. (2016). The implementation of higher order thinking skills at UTY in Indonesia: Opportunities and challenges. Retrieved March 8, 2018, from 
https://www.researchgate.net/publication/32472 0219_The_Implementation_of_Higher_Order_T hinking_Skills_at_Universitas_Teknologi_Yogy akarta_in_Indonesia_Opportunities_and_Challe nges.

Ma, R. (2015). Thesis and dissertation: The role of pronunciation in speaking test ratings. Provo: Brigham Young University.

Manik, S. (2015). Improving students' pronunciation mastery by using English songs. Unpublished master thesis. English Department, Nommensen University.

Rengifo, A. R. (2009). Improving pronunciation through the use of karaoke in an adult English class. Bogotá: Universidad Nacional de Colombia. Retrieved March 1, 2018, from https://revistas.unal.edu.co/index.php/profile/art icle/view/10547/36785.

Riduwan \& Sunarto. (2013). Pengantar statistika. Bandung: Alfabeta.
Ruismäki, H., Antti, J., \& Kimmo, L. (2013). Karaoke-The chance to be a star. The European Journal of Social \& Behavioural Sciences (eISSN: 2301-2218). Paris: C-crcs.

Utami, F. S., Pabbajah, M., \& Juhansar, J., (2018). The implementation of jumbled-sentences toward students' skill in writing report text. English Review: Journal of English Education, 7(1), 115-124. doi: 10.25134/erjee.v7i1.1501.

Voldánová, Ž. (2017). The use of songs in the classroom with a focus on grammatical mistakes. Unpublished bachelor thesis. Department of English Language and Literature, Masaryk University, Brno.

Woo, Y. (2016). Smule connecting the world through music. San Fransisco: Apteligen. Retrieved April 5, 2018 from https://www.apteligent.com/wpcontent/uploads/2016/03/Apteligent-CaseStudy-Smule-0316.pdf. 
Himatul Khoiriyah, Ahmad Mustamir Waris, \& Juhansar

The students' achievement in pronouncing English song using Smule application 